Encuentro №. 97, 86, 2014

\title{
Seguridad y racismo: pensamiento crítico centroamericano
}

Alejandro Flores Aguilar, Clara Arenas y Juan Pablo Gómez (coords.).

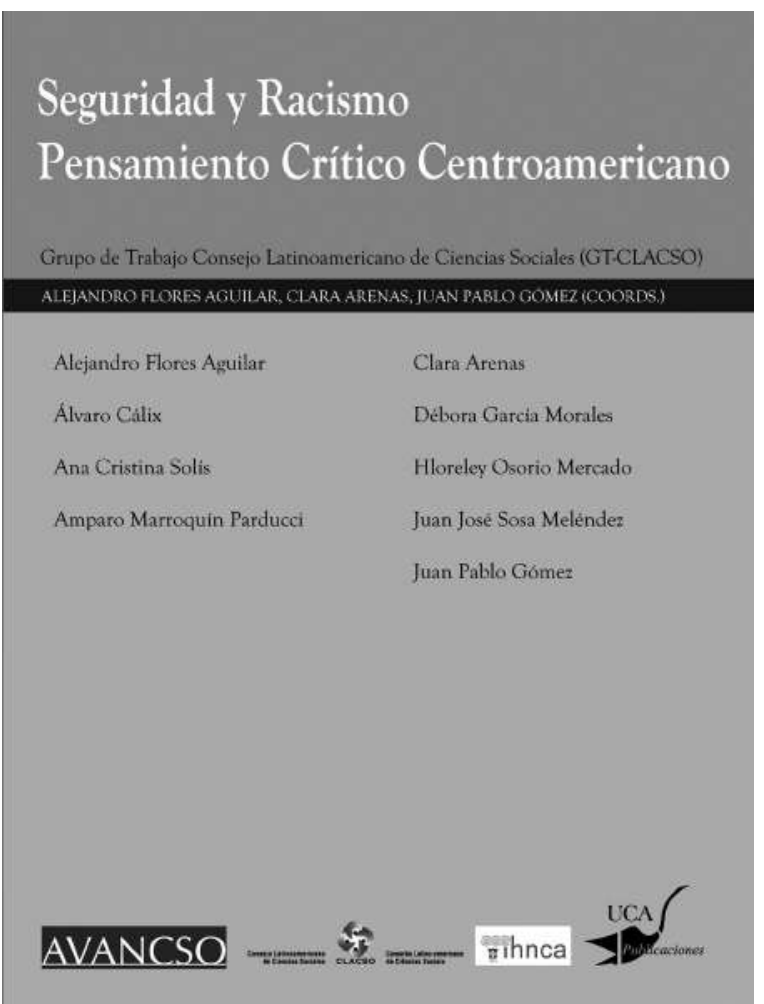

Los artículos reunidos en este volumen son resultado de la primera etapa de reflexión del Grupo de Trabajo del Consejo Latinoamericano de Ciencias Sociales (GTCLACSO), Pensamiento Crítico Centroamericano: seguridad y racismo (20112013). El volumen reúne trabajos sobre Guatemala, El Salvador y Nicaragua. $\mathrm{Su}$ propósito es promover el pensamiento producido desde Centroamérica por investigadores e investigadoras de la región. Con ello queremos aportar nuevas perspectivas analíticas para el estudio de la realidad latinoamericana, ya sea desde el análisis de los procesos sociales recientes de las sociedades centroamericanas, o bien de las principales trayectorias que han configurado la región. 